\title{
Increasing Students' Willingness to Communicate: Drama-Based Approaches to Language Instruction in English for Academic Purposes Classes
}

\author{
Kent K. Lee, Marilyn L. Abbott, E Ning Chen,
}

A strong willingness to communicate (WTC) in a second language is associated with successful language learning. ESL learners with high levels of WTC will seek opportunities to interact in meaningful communication in English. Engagement in meaningful communication is necessary for language learning as it increases access to comprehensible input, promotes negotiation of meaning, and pushes the learner to produce accurate output. By enhancing instructors' understanding of factors that impact students' WTC (e.g., confidence, affect, motivation, and the context of communication), instructors may be better prepared to nurture their students' WTC and expedite their English language acquisition. Because drama-based approaches (DBAs) for teaching English have been found to cultivate a safe learning environment and increase learners' confidence, positive affect, and motivation, these approaches also have considerable potential to improve learners' WTC. Although DBAs may be underutilized in English for academic purposes programs, they are particularly beneficial for students who are hesitant to participate in communicative classroom activities. We review literature on WTC and DBAs, and then incorporate key findings from the literature to guide the development of dramatized role-plays that can foster students' WTC and lead to improvements in students' linguistic and general academic skills.

Une forte volonté de communiquer (VDC) dans une seconde langue est associée à un apprentissage réussi de la langue. Les apprenants d'ALS qui montrent de hauts niveaux de VDC vont rechercher des occasions d'interagir dans des communications utiles en anglais. L'implication dans une communication utile est nécessaire pour l'apprentissage des langues puisqu'elle augmente l'accès à un apport compréhensible, favorise la négociation du sens et pousse l'apprenant à fournir une production précise. En augmentant la compréhension des facteurs qui influencent la VDC des étudiants (par ex. la confiance, l'affect, la motivation et le contexte de la communication) chez les instructeurs, ceux-ci peuvent être mieux préparés pour entretenir la VDC de leurs étudiants et accélérer l'acquisition de l'anglais. On a trouvé que les approches basées sur le théâtre pour l'apprentissage de l'anglais étaient propices à l'entretien d'un environnement d'apprentissage sécurisant et augmentaient la confiance des apprenants, leur affect positif, ainsi que leur motivation et qu'elles présentent un potentiel considérable pour améliorer la VDC des apprenants. Bien que ces approches ne soient pas 
beaucoup utilisées dans les programmes de cours d'anglais académique, elles sont particulièrement bénéfiques chez les étudiants qui hésitent à participer aux activités de communication en classe. Nous examinons la recherche et l'approche basée sur le théâtre et incorporons les résultats-clés de la recherche pour guider le développement de jeux de rôles mis en scène qui peuvent favoriser la VDC et améliorer les compétences linguistiques et universitaires des étudiants.

Keywords: willingness to communicate (WTC), English for academic purposes (EAP), role-play

Canada is a popular destination for international students (El-Assal, 2020; Immigration, Refugees and Citizenship Canada, 2020), many of whom enroll in English for academic purposes (EAP) classes. EAP instructors may find that some of their students avoid participating in class discussions and other communicative activities (Jackson, 2003; Hsu, 2015). Students' unwillingness to communicate has been attributed to their high levels of language anxiety and lack of security and comfort in communicating in English (Wang et al., 2017). Feelings of emotional insecurity can contribute to shyness and withdrawal from communicating in EAP speaking tasks (Fallah, 2014; Girardelli et al., 2017; Hsu, 2015) such as responding to impromptu questions or expressing opinions on novel topics. Instructors may address this insecurity and increase students' willingness to communicate (WTC) in English by providing them with preparation and planning time, and opportunities to become familiar with the topics/contexts of the communication and to interact in a nonthreatening, supportive learning environment (Chichon, 2019; Keefe \& Shi, 2017). The use of drama-based approaches (DBAs) in second language (L2) instruction has been found to enhance students' oral fluency (Araki \& Raphael, 2018; Galante \& Thomson, 2017), comprehensibility (Galante \& Thomson, 2017), confidence and motivation (Araki \& Raphael, 2018), and to reduce their anxiety (Carson, 2012; Galante, 2018). If students are fluent, comprehensible, confident, and motivated users of the L2, they will be more willing to communicate with others in the L2 (MacIntyre, 2012). Although EAP instructors may refrain from using drama tasks and activities (Belliveau \& Kim, 2013), DBAs can foster key individual and situational variables underlying WTC that contribute to successful L2 learning and effective academic communication. In this paper, we review literature on WTC and DBAs, and then present a research-informed framework for developing EAP students' WTC and English language and academic skills through dramatized role-play. 


\section{Literature Review}

WTC in an L2

WTC is defined as "a readiness to enter into discourse at a particular time with a specific person or persons, using a L2" (MacIntyre et al., 1998, p. 547). Because L2 learning requires exposure to massive amounts of L2 input and extensive opportunities to produce language and negotiate meaning during L2 interactions (Gass \& Mackey, 2020; Long, 2015), learners' willingness to engage in meaningful L2 communication will increase their access to interaction and contribute to successful L2 learning. MacIntyre et al. (1998) conceptualized WTC as a dynamic construct that is influenced by numerous interrelated individual factors (e.g., confidence, affect, motivation) and situational factors (e.g., communicative context and people involved). For example, changes in the students' psychological states, familiarity with and number of interlocutors, and the type and topic of the activities can either encourage or restrain WTC (Cao, 2014; MacIntyre, 2012). Due to the complexity of WTC, a discussion of all the factors that influence a learners' WTC in an L2 is beyond the scope of this paper. Therefore, we chose to focus on the most salient predictors of WTC that DBAs have been demonstrated to enhance. In a recent meta-analysis of WTC, motivation and anxiety were key predictors of WTC across 11 studies (Shirvan et al., 2019). Other researchers have also found that self-confidence (Khajavy et al., 2016) and communicative context (Cao \& Philp, 2006; Peng, 2019) positively impact students' WTC. In language teaching contexts such as the EAP classroom, individual and situational factors combine to affect WTC (Cao, 2014; Chichon, 2019). Given the relationships between these factors and WTC, the design and implementation of pedagogical activities that positively influence these individual and situational factors can promote EAP students' WTC and, in turn, foster their L2 communicative competence (Edwards \& Roger, 2015; Zhang et al., 2019).

\section{L2 Confidence and WTC}

L2 confidence is the belief in one's ability to communicate effectively in the L2 (MacIntyre et al., 1998). Researchers have reported that L2 confidence positively impacts one's WTC (Gallagher, 2013; Khajavy et al., 2016; Peng \& Woodrow, 2010). Communicative tasks such as working on group presentations have been found to improve EAP students' L2 confidence (Keefe \& Shi, 2017); however, in order to partake in these tasks, learners must be willing to communicate. Edwards and Roger (2015) observed a reciprocal cycle of continuous improvement where a rise in L2 confidence led to an increase in WTC which led to improvements in L2 communication and vice versa. This research suggests that by building students' confidence in their 
ability to cope with the demands of L2 communication, instructors will be able to raise their students' WTC and ultimately improve their L2 competence.

\section{Anxiety and WTC}

Anxiety is an emotion characterized by negative feelings and insecurities that arise during L2 learning and reduce learners' WTC (Cao, 2014; Gallagher, 2013; Khajavy et al., 2018; MacIntyre, 2007; Peng \& Woodrow, 2010; Shirvan et al., 2019). Emotional insecurities and shyness negatively affect both confidence and WTC (Fallah, 2014; Girardelli et al., 2017). MacIntyre (2012) suggests that to encourage students' WTC, it is necessary to recognize when anxiety is restraining students' communication and then help them implement strategies to manage their anxiety.

\section{Motivation and WTC}

Motivation is the force that influences actions, persistence and efforts, and as a result is an important factor in both L2 learning (Dörnyei, 2018) and WTC (Shirvan et al., 2019). If the process of language learning is enjoyable and satisfying, learners will be more motivated and willing to use the language (MacIntyre et al., 1998). Instructors can influence students' motivation by (a) designing and implementing interesting, relevant classroom tasks that have a high probability of successful completion (Dörnyei, 2018; Lamb, 2017); and (b) using motivational strategies such as "explaining the purpose and utility of the tasks" (Dörnyei, 2001, p. 79). Although motivation, like WTC, may fluctuate over time according to changes in individual and situational factors (MacIntyre, 2012), instructors can maintain students' motivation to communicate through the use of supportive pedagogical approaches (Lamb, 2017).

\section{Communicative Context and WTC in EAP}

The context in which L2 learning occurs (e.g., the EAP classroom) also influences students' WTC (Cao, 2014). The purpose of EAP is to prepare students for studying, conducting research, and communicating in English in academic contexts where learners are expected to comprehend and critically evaluate academic readings and clearly articulate their ideas in academic papers, presentations, and discussions. Participation in academic discourse requires WTC, and WTC has been found to predict students' final grades in an EAP course (Zhang et al., 2019). Aspects of academic classroom environments that have been demonstrated to positively influence English learners' WTC include supportive instructors, cohesive class cultures, and relevant tasks that promote students' interest and success (Khajavy et al., 2016; Peng, 2019; Peng \& Woodrow, 2010). The creation of communicative tasks with a clear purpose and familiar content, and the assignment of predefined roles for class activities have also been shown to advance EAP students' WTC (Chichon, 
2019). Pedagogical approaches that EAP instructors can use to enhance key factors that converge to positively influence students' WTC include the use of drama.

\section{Drama-Based Approaches in L2 Teaching}

Drama is an effective L2 teaching tool that relies on the use of pantomime and scripted, semi-scripted, or entirely improvised language to communicate in imagined scenarios (Galante, 2018). To develop EAP students' abilities to effectively engage in extemporaneous or spontaneous academic communication and to reduce their reluctance to speak, instructors can use L2 drama tasks and activities where the amount of extemporaneous communication required is gradually increased across a continuum of DBAs from controlled to open communication (Kao \& O'Neill, 1998). Controlled approaches involve the use of pre-scripted language in short role-plays and skits. Semi-controlled approaches combine both scripted and improvised language in simulations and real-world scenarios in which students determine the outcomes/endings. Open communication refers to unscripted extended improvised process drama that is more complex than the other two approaches. A process drama may begin with the instructor and learners adopting imaginary roles in relation to a particular scenario that is elaborated upon over time. Throughout the drama, both the instructor and the learners engage in unscripted exchanges from their characters' points of view, which may result in unforeseen problems that require further interactions over a series of episodes. During these episodes, students may engage in preparation activities, rehearsals, interviews, written assignments, and spontaneous improvisations. These activities are intended to promote deeper connections to the characters and allow opportunities to explore complex issues in future episodes. However, the production of improvised language in DBAs requires WTC. To reduce EAP students' reluctance to speak in English prior to a process drama, Araki and Raphael (2018) successfully used miming activities in which students reflected on the sources of their hesitation and then visualized their negative emotions as articles of clothing (e.g., "coat of self-consciousness ... pants of nervousness," p. 50) which they cast off one by one.

Additional benefits of DBAs include reducing students' language anxiety (Carson, 2012; Galante, 2018) and increasing their language proficiency (Carson, 2012), oral fluency (Araki \& Raphael, 2018; Galante \& Thomson, 2017), written fluency (Araki \& Raphael, 2018), comprehensibility (Galante \& Thomson, 2017), confidence and motivation (Araki \& Raphael, 2018), and collaboration (Carson, 2012) in a safe, playful environment (Shapiro \& Leopold, 2012). Galante and Thomson (2017) concluded that the "repetitive fluency-building activities present in drama activities can promote transfer to more fluent extemporaneous speech" (p. 132). Research findings also indicate 
that the use of drama activities such as process drama (Araki \& Raphael, 2018) and role-plays (Shapiro \& Leopold, 2012) increases EAP students' levels of engagement, interaction, and critical thinking. Because many of the benefits associated with DBAs also contribute to several of the salient factors that create WTC (i.e., confidence, affect, motivation, and a safe context for communication), we argue that the convergence of all of the benefits of DBAs provides a strong rationale for using drama-based L2 instructional approaches to increase EAP learners' WTC, L2 competence, and general academic skills.

\section{Creating Dramatized Role-Plays that Promote WTC}

In this section, we provide a research-informed framework to guide the creation of dramatized role-plays that has been effective in fostering students' WTC in the third author's undergraduate EAP speaking and listening classes at a Canadian university. Her students found the dramatized role-plays motivating, enjoyable, and effective in (a) developing their English language, critical thinking, and research skills, and (b) increasing their confidence in their L2 ability. She also noted that the tasks and activities outlined in the ensuing framework built greater rapport among her students so they felt safe when communicating in class, and as a result, they tended to speak more during the drama activities than they did when completing typical EAP discussion activities.

The following dramatized role-play framework consists of three phases: preparing for, experiencing, and reflecting on the play/drama. Activities in these three phases include selecting the scenario, researching the scenario, selecting characters, collaborative scriptwriting, miming, rehearsing, performing, reflecting and critiquing the performance. Three example roleplay scenarios dealing with discipline-specific topics commonly found in EAP texts (art, science, and philosophy) that are intended to be used with the framework are presented below in the section titled "Examples of DBA Role-Plays."

\section{Phase One-Preparing for the Drama}

The goals of preparing for the drama are to (a) develop students' academic skills (e.g., reading, writing-summarizing/paraphrasing/evaluating/ synthesizing-library research, critical thinking, oral communication, collaborative problem solving, and awareness of the language and discourse features of a variety of text structures and the contexts in which they are used); (b) prepare students to apply these academic skills in the design of role-play scripts that employ language forms and functions that are appropriate for a selected discipline-specific scenario; and (c) foster students' WTC. 
1. Instructors begin with a discussion of WTC, its importance in both L2 learning and EAP, and the potential of DBAs to increase learners' WTC. To facilitate this discussion, instructors assign an article on WTC (e.g., MacIntyre, 2012 or sections of it) and then discuss the ideas in class.

2. Then by employing a motivational strategy (i.e., "explaining the purpose and utility of a task" [Dörnyei, 2001, p. 79]), instructors provide students with an overview of the role-play framework and explain the purpose and value of the upcoming activities. The use of such strategies is "conducive to the development of a cohesive learning community" (Dörnyei, 2018, p. 4) that can contribute to a safe environment for communication and increase students' WTC (Khajavy et al., 2016; Peng, 2019; Peng \& Woodrow, 2010).

3. The next step is to select the scenario for the drama (for EAP scenario ideas, see examples in the section below titled "Examples of DBA RolePlays"). Instructors could involve students in the scenario selection, as involving students in decision-making has been found to increase motivation (Dörnyei, 2001).

4. Then students prepare for the role-play by researching the context of the scenario (Shapiro \& Leopold, 2012), selecting their characters, collaborative scriptwriting (Carson, 2012), and completing miming activities (Araki \& Raphael, 2018). By conducting research (e.g., online, library, and/or field) students become familiar with the topic, setting, and characters depicted in the role-play scenario, as well as the associated discipline-specific language forms and functions. Familiarity with the scenario facilitates character selection, scriptwriting, and the students' abilities to express their ideas in the L2.

All of these pre-planning activities can create WTC in EAP, as they address a combination of factors that underlie WTC (Shirvan et al., 2019) and align with EAP learning goals. In addition to building familiarity with the topic of communication, the selection of predefined roles has been found to significantly influence students' WTC in EAP (Chichon, 2019). Working collaboratively on scripts can enhance group rapport (Carson, 2012), and group cohesiveness can contribute to a positive classroom environment which, in turn, fosters WTC (Peng, 2019; Peng \& Woodrow, 2010). Conducting research and scriptwriting can also help EAP students critically examine complex issues from multiple perspectives (Shapiro \& Leopold, 2012) and improve their English language proficiency (Carson, 2012). Fun miming activities, such as casting aside a shirt of anxiety, can emotionally prepare the learners for L2 production (Araki \& Raphael, 2018), and anxiety-reducing activities can also encourage learners' WTC (MacIntyre, 2012). 


\section{Phase Two-Experiencing the Drama}

The second phase in the dramatized role-play, experiencing the drama, entails rehearsal(s) and a possible final performance. In this phase, students will continue (a) developing their oral communication skills, spoken fluency, and WTC, and (b) learning how to work collaboratively as members of a team to prepare them for collaborative tasks in disciplinary courses. Through the rehearsal of scripted or (semi-) improvised role-plays in nonthreatening environments, students can improve their fluency, which is transferable to other EAP tasks; and task rehearsal (Jamalifar \& Salehi, 2020) and predefined roles (Chichon, 2019) can improve students' WTC. The rehearsal of collaboratively written scripted or semi-scripted role-plays can remove the stress of extemporaneous speech production and increase students' confidence in their ability to cope with the linguistic demands of the roleplay, as rehearsals have been shown to reduce EAP students' speaking anxiety (Carson, 2012). In addition, rehearsals can provide students with safe, supportive spaces (Piazzoli, 2011) to (a) deepen their understanding of their characters and the scenario through interacting with their peers, and (b) practise communicating in the L2 using appropriate language forms and functions. To create flexible, supportive, safe rehearsal spaces in which students are willing to communicate, instructors could emphasize that "mistakes are the by-product of experimentation and should not be feared" (Araki \& Raphael, 2018, p. 48), and students could be allowed to select their own groups and to rearrange the classroom or use breakout rooms to rehearse.

\section{Phase Three-Reflecting on the Drama}

In this phase, students will consolidate their learning by reflecting on, discussing, and writing about how the role-play activities impacted their language development and WTC. Reflection is inherent in any drama, as "drama...is an invitation to reflection about the human condition" (Bruner, 1986, p. 128). Reflections can help learners recognize and track their learning progress (Kao \& O'Neill, 1998) and their WTC. When students see improvements in these areas, their success can build their confidence and motivation to continue learning and communicating in the L2, and language learning achievement, increased confidence and motivation have been shown to collectively contribute to WTC (Khajavy et al., 2016). To guide student reflection on the role-play, their language development, and their WTC, instructors could pose the following questions (or other teacher- or studentgenerated questions) and then have students reflect individually and discuss their responses in pairs or small groups.

1. How did the role-play activities affect your WTC? What could help you to improve your WTC in the future? 
2. What did participating in the role-play teach you about English?

3. What did acting as the character in the role-play teach you about yourself, that particular character's role in the scenario, the relationships among others in the role-play, or life in general?

4. What went well? Why?

5. What did not go well? Why?

6. How could your responses to these questions be used to improve the next rehearsal/episode/performance?

Students could also be asked to write a reflective journal on their experiences with the drama (Araki \& Raphael, 2018) and changes in their WTC over the three phases of the role-play. For example, students could write a journal entry at the end of each role-play activity in which they relate their experiences to MacIntyre's (2012) WTC article assigned in phase one.

\section{Examples of DBA Role-Plays}

To implement the role-play framework, instructors/students must choose a scenario. In this section, we selected three scenarios and developed them into dramatized role-plays. Each role-play is intended to follow the three phases of the framework described above. The scenarios are based on discipline-specific topics commonly found in EAP materials: art, science, and philosophy. The role-plays have the potential to effectively create WTC while developing students' L2 competence and general academic skills.

\section{Controlled DBA-Scripted Role-Play}

The topic of modern art could be dramatized within the scenario of a guided tour of an art museum. Roles/characters in the drama for the students include artists, tour guides, and visitors. In groups, students (a) choose a famous art museum that has a virtual gallery (e.g., the Louvre, the MET) and a famous artist, (b) prepare a script for a themed tour of the artist's work, (c) prepare questions for the visitors to ask the artists, and (d) prepare the artists' responses. Depending on the class time available, the instructor could have the students perform the tour in class or record their tours and post the recordings on their online class or website.

\section{Semi-Controlled DBA-Semi-Scripted Role-Play}

For the topic of climate change, interviewing a panel of climate change experts, activists, and deniers on a live, televised news segment could serve as a role-play setting. Some learners could act as different climate experts 
(e.g., David Phillips, Nigel Lawson), activists (e.g., Al Gore, Greta Thunberg), and deniers (e.g., Michael Moore, Steve Milloy), while others take the role of reporters (e.g., David Suzuki, David Attenborough). To prepare for the role-play, all of the actors would need to undertake research on climate change-the panelists prepare a 3-minute script outlining their stance and the reporters create introductions and questions for each of the panelists. The panel interview begins with the reporter's introductions. Then members present their outlines. After the panelists' presentations, the reporters pose their prepared and any additional impromptu questions and the panelists improvise their responses.

\section{Open Communication DBA-Ongoing Improvised Role-Play}

Ethical topics are often explored in television series or movies. For example, The Good Place (2016-2020) is a popular comedy series that could engage students in communicating about ethical issues/moral dilemmas portrayed in particular scenes. Students could (a) watch a scene depicting an issue (e.g., the Trolley Problem, season 2, episode 6), (b) research the issue, (c) choose a role as one of the philosophers mentioned in the series (e.g., Thomas Aquinas, Aristotle, Jeremy Bentham, Albert Camus, Jonathan Dancy, Philippa Foot, Martin Heidegger, David Hume, Immanuel Kant, Søren Kierkegaard, John Locke, Thomas Nagel, Martha Nussbaum, Plato, Jean-Paul Sartre, Thomas Scanlon, Judith Thompson, Bernard Williams), and (d) research the philosopher to determine how the philosopher would deal with the issue. Then acting as philosophers, they interview other philosophers to find those who would resolve the ethical dilemma in a similar manner. Once they have found other like-minded philosophers, they attempt to convince the trolley driver to do what they believe is ethical. In this episode, the instructor could participate as the trolley driver, and in doing so, support and/or challenge students throughout the role-play. To extend the process drama, other ethical dilemmas featured in the series could be resolved through a similar or modified process with the students playing the same or other characters.

\section{Conclusion}

The use of the research-informed three-phase dramatized role-play framework with the discipline-specific scenarios outlined in this paper can provide EAP students with opportunities to engage in meaningful communication, build rapport with peers, and learn how to cope with negative emotions that inhibit their WTC. Dramatized role-play activities can be powerful tools for creating safe, supportive, enjoyable, interactive, motivating language learning environments that bolster students' confidence, build their academic communication skills, and reduce their hesitancy to communicate. Given that salient factors underlying WTC (i.e., increased confidence, reduced anxiety, 
enhanced motivation, and a safe context for communication) materialize and converge as benefits of DBAs, drama-based L2 instructional approaches in EAP classes have tremendous potential for increasing students' WTC and advancing their language learning and general academic skills.

\section{The Authors}

Kent K. Lee is an assistant professor in the TESL Program in the Department of Educational Psychology at the University of Alberta. Email: kent.lee@ualberta.ca

Marilyn L. Abbott is a professor in the TESL Program in the Department of Educational Psychology at the University of Alberta.

Ning Chen is an experienced EAP instructor who holds a Master in TESL from the University of Alberta.

\section{References}

Araki, N., \& Raphael, J. (2018). Firing the imagination: Process drama as pedagogy for 'melting' EAP speaking anxiety and increasing Japanese university students' confidence in speaking. In R. Ruegg \& C. Williams (Eds.), Teaching English for academic purposes (EAP) in Japan (pp. 41-48). Springer. https://doi.org/10.1007/978981-10-8264-1_3

Belliveau, G., \& Kim, W. (2013). Drama in L2 learning: A research synthesis. Scenario, VII(2), 7-27. http://research.ucc.ie/scenario/2013/02/BelliveauKim/02/en

Bruner, J. (1986). Actual minds, possible worlds. Harvard University Press.

Cao, Y. (2014). A sociocognitive perspective on second language classroom willingness to communicate. TESOL Quarterly, 48(4), 789-814. https://doi.org/10.1002/tesq.155

Cao, Y., \& Philp, J. (2006). Interactional context and willingness to communicate: A comparison of behavior in whole class, group and dyadic interaction. System, 34(4), 480-493. https://doi. org/10.1016/j.system.2006.05.002

Carson, L. (2012). The role of drama in task-based learning: Agency, identity and autonomy. Scenario, VI(2), 47-60. http://research.ucc.ie/scenario/2012/02/Carson/06/en

Chichon, J. (2019). Factors influencing overseas learners' willingness to communicate (WTC) on a pre-sessional programme at a UK university. Journal of English for Academic Purposes, 39, 87-96. https://doi.org/10.1016/j.jeap.2019.04.002

Dörnyei, Z. (2001). Motivational strategies in the language classroom. Cambridge: Cambridge University Press.

Dörnyei, Z. (2018). Motivating students and teachers. In J. I. Liontas \& M. DelliCarpini, The TESOL encyclopedia of English language teaching. Wiley. https://doi.org/10.1002/9781118784235. eelt0128

Edwards, E., \& Roger, P. S. (2015). Seeking out challenges to develop L2 self-confidence: A language learner's journey to proficiency. TESL-EJ, 18(4), 1-24. http://tesl-ej.org/pdf/ej72/ a3.pdf

El-Assal, K. (2020, February). 642,000 international students: Canada now ranks 3rd globally in foreign student attraction. CIC News. https://www.cicnews.com/2020/02/642000-internationalstudents-canada-now-ranks-3rd-globally-in-foreign-student-attraction-0213763. html\#gs.6x3kag

Fallah, N. (2014). Willingness to communicate in English, communication self-confidence, motivation, shyness and teacher immediacy among Iranian English-major undergraduates: A structural equation modeling approach. Learning and Individual Differences, 30, 140-147. https://doi.org/10.1016/j.lindif.2013.12.006 
Galante, A. (2018). Drama for L2 speaking and language anxiety: Evidence from Brazilian EFL learners. RELC Journal, 49(3), 273-289. https://doi.org/10.1177/0033688217746205

Galante, A., \& Thomson, R. I. (2017). The effectiveness of drama as an instructional approach for the development of second language oral fluency, comprehensibility, and accentedness. TESOL Quarterly, 51(1), 115-142. https://doi.org/10.1002/tesq.290

Gallagher, H. C. (2013). Willingness to communicate and cross-cultural adaptation: L2 communication and acculturative stress as transaction. Applied Linguistics, 34(1), 53-73. https://doi.org/10.1093/applin/ams023

Gass, S., \& Mackey, A. (2020). Input, interaction, and output in L2 acquisition. In B. VanPatten, G. D., Keating, \& S. Wulff (Eds.), Theories in second language acquisition: An introduction (pp. 192-222). Taylor \& Francis. https://doi.org/10.4324/9780429503986

Girardelli, D., Patel, V. K., \& Martins-Shannon, J. (2017). “Crossing the rubicon": Understanding Chinese EFL students' volitional process underlying in-class participation with the theory of planned behaviour. Educational Research and Evaluation, 23(3), 119-137. https://doi.org/10 $.1080 / 13803611.2017 .1398668$

Hsu, W. H. (2015). Transitioning to a communication-oriented pedagogy: Taiwanese university freshmen's views on class participation. System, 49, 61-72. https://doi.org/10.1016/j. system.2014.12.002

Immigration, Refugees and Citizenship Canada. (2020). Temporary residents: Study permit holders - monthly IRCC updates. https://open.canada.ca/data/en/dataset/90115b00-f9b8-49e8afa3-b4cff8facaee

Jackson, J. (2003). Case-based learning and reticence in a bilingual context: Perceptions of business students in Hong Kong. System, 31(4), 457-469. https://doi.org/10.1016/j.system.2003.03.001

Jamalifar, G., \& Salehi, H. (2020). The effects of rehearsal and strategic task planning on L2 willingness to communicate. The Language Learning Journal, 48(2), 162-169. https://doi.org/1 $0.1080 / 09571736.2017 .1370605$

Kao, S., \& O'Neill, C. (1998). Words into worlds: Learning a second language through process drama. Alex.

Keefe, K., \& Shi, L. (2017). An EAP program and students' success at a Canadian university. TESL Canada Journal, 34(2), 1-24. https://doi.org/1018806/tesl.v34i2.1260

Khajavy, G., MacIntyre, P., \& Barabadi, E. (2018). Role of the emotions and classroom environment in willingness to communicate: Applying doubly latent multilevel analysis in second language acquisition research. Studies in Second Language Acquisition, 40(3), 605-624. https:// doi.org/10.1017/S0272263117000304

Khajavy, G. H., Ghonsooly, B., Fatemi, A. H., \& Choi, C. W. (2016). Willingness to communicate in English: A microsystem model in the Iranian EFL classroom context, TESOL Quarterly, 50(1), 154-180. https://doi.org/10.1002/tesq.204

Lamb, M. (2017). The motivational dimension of language teaching. Language Teaching, 50(3), 301-346. https://doi.org/10.1017/S0261444817000088

Long, M. (2015). Second language acquisition and task-based language teaching. Wiley.

MacIntyre, P. D. (2007). Willingness to communicate in the second language: Understanding the decision to speak as a volitional process. The Modern Language Journal, 91(4), 564-576. https:// doi.org/10.1111/j.1540-4781.2007.00623.x

MacIntyre, P. (2012). Currents and waves: Examining willingness to communicate on multiple timescales. Contact, 38(2), 12-22. http://contact.teslontario.org/wp-content/ uploads/2016/09/ ResearchSymposium2012.pdf

MacIntyre, P. D., Clément, R., Dörnyei, Z., \& Noels, K. A. (1998). Conceptualizing willingness to communicate in a L2: A situational model of L2 confidence and affiliation. The Modern Language Journal, 82(4), 545-562. https://doi.org/10.1111/j.1540-4781.1998.tb05543.x

Peng, J. (2019). The roles of multimodal pedagogic effects and classroom environment in willingness to communicate in English, System, 82, 161-173. https://doi.org/10.1016/j. system.2019.04.006 
Peng, J., \& Woodrow, L. (2010). Willingness to communicate in English: A model in the Chinese EFL classroom context. Language Learning, 60(4), 834-876. https://doi.org/10.1111/j.14679922.2010.00576.x

Piazzoli, E. (2011). Process drama: The use of affective space to reduce language anxiety in the additional language learning classroom. Research in Drama Education: The Journal of Applied Theatre and Performance, 16(4), 557-573. https://doi.org/10.1080/13569783.2011.617104

Shapiro, S., \& Leopold, L. (2012). A critical role for role-playing pedagogy. TESL Canada Journal, 29(2), 120-140. https://doi.org/10.18806/tesl.v29i2.1104

Shirvan, M. E., Khajavy, G. H., MacIntyre, P. D., \& Taherian, T. (2019). A meta-analysis of L2 willingness to communicate and its three high-evidence correlates. Journal of Psycholinguistic Research, 48, 1241-1267. https://doi.org/10.1007/s10936-019-09656-9

Wang, I., Ahn, J. N., Kim, H. J., \& Lin-Siegler, X. (2017). Why do international students avoid communicating with Americans? Journal of International Students, 7(3), 555-582. https://doi. org/10.5281/zenodo.570023

Zhang, J., Beckmann, N., \& Beckmann, J. F. (2019). One situation doesn't fit all: Variability and stability of state willingness to communicate in a Chinese college English classroom. Language Teaching Research. Advance online publication. https://doi.org/10.1177/1362168819891330 